of yesteryear, either out of pure intellectual engagement or a desire to micromanage.

Philanthropic organizations tend to be interested in particular outcomes, rather than in simply funding the most academically interesting question that presents itself. They may take a more business-like approach, too, demanding milestones and results. And they can show a greater readiness to turn off the funding if these things are not forthcoming - or, in some cases, simply if the stock market takes a tumble.

The mixture of risk tolerance and accountability seen in some foundations, particularly those concerned with a specific disease, may seem contradictory, but it need not be so. What matters to the administrators who dole out the cash is normally not success per se, but demonstrated diligence in following the risky strategy set down. This level of accountability can make some researchers uncomfortable (see page 252). If basic researchers expect to benefit from these disease-focused foundations, they need to make a compelling case that their studies offer a real chance of progress towards a cure, and to document the way those chances play out.
This does not mean that the donor is always right, however. There are real risks that some areas of biomedical research could be dominated by a few rich people and the boards on which they sit, with little guidance from scientific consensus or expertise. Philanthropic groups need to think carefully about how best to award money, and to realize that no single strategy will succeed in every case. What's right for Huntington's disease, where a faulty gene has been named and shamed, may be wrong or premature for something more complex, such as autism. Rushing into the wrong strategy will merely waste time and money.

In the end, though, it is the philanthropists' money to waste. They would obviously be wise to make sure that the money is well spent, but they cannot always be stopped from other courses. Rather, it is for the scientists who stand to benefit from such largesse to ask themselves whether the money on offer is worth the risks of the course being prescribed. By doing so, and by helping donors identify the most pressing scientific questions relevant to their remit, the scientific community can help make the most of the new diversity offered by the philanthropy boom.

\section{Blurred vision}

\section{In the end, the European Institute of Technology will not be worthy of its title.}

t could have been inspiring. Imagine a university set up to educate some of the best students from Europe and beyond, and to provide a home for the world's most creative researchers in the natural sciences and engineering. It would be an institution with an outstanding new campus, benefiting from annual revenues of at least $€ 500$ million (US\$700 million) - a pinnacle scholars would aspire to and entrepreneurs would move to be close to.

That is what the European Institute of Technology (EIT) might have been. It was what was implicit in the idea that the president of the European Commission, José Manuel Barroso, put forward under that name in 2005. The proposal that now goes by the name of the EIT is a paltry thing by comparison - a small, central, administrative executive that would select 'knowledge and innovation communities' (KICs) to fund research in promising-sounding areas. The KICs would be distributed networks made up of 'partnerships' between organizations in the education, research and business sectors, and would confer postgraduate degrees. The commission would contribute $€ 2.4$ billion between 2008 and 2013 .

An expert group commissioned by the European Parliament to analyse this proposal recommended a different way forward last month. In this vision, too, there is no central EIT - but the KICs become genuine bricks-and-mortar institutes, 20 or so of them, each with 300-odd scientists, located in regions where there is already established research strength.

Parliament, however, seems not to be taking its experts' advice. Both it and the European Council - the two decision-making bodies of the European Union - are likely to approve the commission's lack-lustre notion of virtual networks. And both are downplaying the element of education, toying with the idea that the EIT and its components might offer some sort of watered-down postgraduate diploma without the clout of a PhD.

So Europe will get yet another virtual industry-academic network, to sit alongside the Framework Programme's Networks of Excellence, the EUREKA clusters and a welter of other variations on the theme. This shop-worn notion of the EIT has little if any support among researchers. Industry, too, finds it uninteresting.

This delocalized compromise marks a distressing loss of nerve. Europe has a demonstrated ability to deliver enduring world-class research institutions: the particle-physics laboratory CERN and the European Molecular Biology Laboratory stand as evidence. It has shown a willingness to invest in research excellence for its own sake, independent of political agendas - witness the fledgling European Research Council, flooded with applications in its first round of awards. If it chose to, why should the world's largest economy not set up a unitary engineering powerhouse to rival the Massachusetts Institute of Technology, with all the benefits that such scale and ambition confer?

This pitiable state of affairs highlights much of what is wrong with pan-European politics. One fundamental problem is that of 'subsidiarity', a principle embedded in the European Union's foundational Treaty of Rome that requires the commission to steer clear of functions that individual countries are considered to do well enough already, including the award of academic qualifications. Another is a chronic reluctance to commit to bricks and mortar for research.

The German presidency is keen to launch a 'test KIC' next year, specializing in energy efficiency or climate change. It will be a long way from a world-leading academic institution that would have inspired Europe's young people and stimulated its economies. The financial and constitutional challenges involved would have been undeniably great. But the outcome could have been fully worthy of the academic heritage that Europe possesses, and may have stimulated it to new heights. Is that vision now dormant? Or is it dead? 